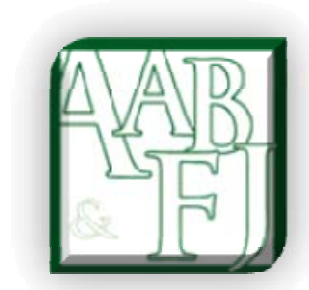

\title{
The Effect of Board Independence on the Earnings Quality: Evidence from Portuguese Listed Companies
}

Sandra Alves ${ }^{1}$

\begin{abstract}
Agency theory suggests that independent outside board members may have an important monitoring function of the financial reporting process. As a result, boards with more independent directors have a tendency for increased monitoring and are therefore expected to insist on better earnings quality. This study examines whether board independence improves earnings quality by reducing earnings management in Portugal, a country with significantly different institutional and legal characteristics from the Anglo-Saxon countries. Using ordinary least square (OLS) and two stage least squares (2SLS) techniques to control potential simultaneity problems between board independence and earnings quality, we find evidence that independent board members improve earnings quality by reducing earnings management for a sample of Portuguese listed firms. This result suggests that strengthening the independence of boards by appointing more independent board members is a positive step toward improving earnings quality.
\end{abstract}

JEL Classification: M410, G32, G34

Keywords: board independence, earnings quality, discretionary accruals

${ }_{1}^{1}$ School of Accountancy and Administration, University of Aveiro sandra.alves@ua.pt 


\section{Introduction}

Boards of directors are the primary element of corporate governance because they are responsible for monitoring the quality and the integrity of the company's financial reports and controlling top management, as delegated by shareholders (Fama \& Jensen 1983). Portuguese's company law establishes that the boards of directors have the responsibility to monitor the firm's accounting system and the financial statements. Board monitoring of the financial reports is important because managers often have self-interested incentives to manage earnings, potentially misleading shareholders.

An important factor that may affect the ability of the board to monitor the firm's managers is its composition and the percentage of independent directors on the board (Fields \& Keys 2003). According to agency theory, one important mechanism designed to reduce agency problems is the appointment of independent directors on the corporate board. Independent outside directors are motivated to avoid colluding with managers because the human capital value of independent directors is partially determined by the effectiveness of their monitoring performance (Fama 1980; Fama \& Jensen 1983). The external stakeholders will require independent outside board members to monitor financial reporting and internal transactions, with a sufficient level of external scrutiny, and according to a prescribed set of expectations (Lynall et al. 2003). Therefore, as monitors of management, independent outside directors play an important oversight and monitoring role in corporate governance.

Previous studies based, mainly, on data of US and UK firms conclude that corporations with independent boards tend to have less earnings management (e.g. Dechow \& Dichev 2002; García-Meca \& Sánchez-Ballesta 2009; Koa \& Chen 2004; Mather \& Ramsay 2006; Peasnell et al. 2000, 2005). For example, Klein (2002), using US data, finds negative associations between abnormal accruals and the percentage of outside directors on the board, and to whether the board is comprised of less than a majority of outside directors. Similar results were also reported by Ebrahim (2007), Epps \& Ismail (2009), Farber (2005), Uzun et al. (2004) and Xie et al. (2003). Peasnell et al. (2000, 2005) analyse a sample of UK firms, concluding that the likelihood of income increasing accruals decreases with an increase of the independence of the board. Garcia Osma (2008) also uses a sample of UK firms to study whether independent boards are efficient at detecting and constraining myopic R\&D cuts. The results indicate that more independent boards constrain the manipulation of $R \& D$ expenditure. Davidson et al. (2005) find empirical support for the effective role of independent directors in constraining earnings management in Australian firms. This suggests that independent directors are able to better protect shareholders from managerial opportunism. Therefore, board independence may improve earnings quality by reducing earnings management. Ahmed \& Duellman (2007) and Beekes et al. (2004) find that an independent board improves the quality of reported earnings for a sample of US firms and for a sample of UK firms, respectively.

Independent directors on the board may improve earnings quality by mitigating managerial self-interest and by monitoring and controlling the production of financial statements by management. Accordingly, boards with more independent directors have a propensity for greater monitoring and are therefore expected to insist on greater earnings quality. Hence, we expect that board independence will improve earnings quality by limiting earnings management.

Thus, in this study, we examine the effect of board independence (measured by the proportion of independent non-executive directors on the board) to the earnings quality, hypothesising that board independence enhance the earnings quality by limiting the extent of discretionary accruals. In particular, earnings are expected to be more informative when a

high fraction of independent outside directors serves on the board. We focus on independent 
non-executive directors for two reasons. First, board independence is the centre of recent regulatory intervention and public policy debate. Second, board independence is a commonly used indicator of corporate governance strength.

In using ordinary least square and two stage least squares techniques to control potential simultaneity problems between board independence and earnings quality on a sample of 33 Euronext Lisbon non-financial firms over a period of 8 years (2003 to 2010), we find evidence that independent board members improve earnings quality by reducing earnings management. This finding suggests that strengthening the independence of boards by appointing more independent board members is a positive step toward improving earnings quality. Thus, it indicates that independent board members provide effective monitoring of earnings management in Portuguese listed firms.

The study makes some contributions to the existing literature. The study contributes to the earnings quality literature and board literature, by showing the effect of independent director members on earnings quality beyond the US and the UK environments. The work is particularly important to Portugal, where the knowledge on the impact of board independence on earnings quality is still limited. In addition, the Portuguese market presents a unique case in studying the impact of board independence on earnings quality. The Portuguese market has a very different corporate governance structure, characterised by concentrated firm ownership and a strong bank presence, in contrast with the ownership in the US and in the UK listed firms (Shleifer \& Vishny 1997; Silva et al. 2006). These differences suggest that agency conflicts are likely to be greater in Portuguese firms than in their US and UK listed firms counterparts (La Porta et al. 2000). Thus, this paper adds to the literature by being the first to provide empirical evidence on this issue in Portugal. In addition, this paper, in contrast to similar studies, addresses the potential simultaneity problem between independent directors and earnings quality.

The findings of this study are very important to regulators and investors, which are concerned about earnings management and improving the quality of financial reporting. They will also be important to investors to evaluate the impact of board independence on earnings quality, especially in concentrated ownership firms.

This paper is structured as follows. In section two, we give a brief overview of the Portuguese Securities Market Supervisory Authority (Comissão de Mercado de Valores Mobiliários, henceforth "CMVM") recommendations for independent board members. The literature review and the development of testable hypotheses are presented in section three. Section four describes the methodology, while section five reports the main results. We

provide sensitivity tests in section six. Finally, section seven summarises and concludes this paper.

\section{CMVM Recommendations for Independent Board Members}

The corporate board structure in Portugal is similar to those existing in other European countries. It consists of a single-tier system, without a separate supervisory board. The single board comprises the CEO, other executive managers, and non-executive directors. In this single-tier system, the prescribed role of non-executive board members is to protect the interests of shareholders in key decisions to the company. They are supposed to bridge the gap between uninformed shareholders and informed executive managers.

In October 1999, the CMVM issued a set of 17 voluntary corporate governance best practices (CMVM Regulation No. 7), which required Portuguese listed companies to disclose annually their corporate governance practices, and to compare their practices to the 17 best practices recommendations on different subjects regarding corporate governance. These 
recommendations, in accordance with CMVM Regulation No. 7, were implemented on a comply-or-explain basis in 2001 (these recommendations have been revised and updated regularly). They were classified by CMVM Regulation No. 7 into 5 distinct groups: i) disclosure of information; ii) voting and shareholder representation; iii) adoption of certain society rules; iv) structure and operation of the board of directors; and v) institutional investors (Alves \& Mendes 2001).

Regarding the independence of the board of directors, the CMVM's recommendations (CMVM Regulation 10/1999 as amended by CMVM Regulation 7/2001, CMVM Regulation 11/2003, CMVM Regulation 10/2005 and CMVM Regulation 3/2006) establish that the number of non-executive directors should exceed by far the number of members of the executive board. Among the non-executive members there should be members that are independent from the executive directors, from the main shareholders, and members with no materially relevant business or relations to not interfere with their freedom of judgment. When there is only one non-executive director, he/she must also be independent.

As the UK's Higgs report (Higgs 2003) and the USA's Sarbanes-Oxley Act of 2002, CMVM's recommendations also emphasise the importance of independent directors to listed firms. This suggests that regulators consider independent board members as important monitors.

\section{Literature Review and Testable Hypotheses}

According to agency theory, separation of ownership and control leads to a divergence in the pursuit of managerial interests versus owners' interests (Jensen \& Meckling 1976), and thus monitoring managerial decisions becomes essential for boards of directors to assure that the interests of shareholders are protected (Fama \& Jensen 1983).

In an agency setting, featured by concentrated ownership agency, conflicts happen between large controlling shareholders and minority outside investors, with risks of exploitation of private benefits. Dominant shareholders may seek to maximise their own utility and expropriate wealth from other investors as well as from other stakeholders (Shleifer \& Vishny 1997; Holderness 2003). Therefore, while large insider shareholders can exploit the benefits of private control, having direct access to information, outsider shareholders rely on the monitoring activity of the board of directors.

Boards of directors are formed to monitor managers on behalf of their shareholders (Eisenhardt 1989; Jensen \& Meckling 1976). Agency theory stresses that board independence has a positive effect on board effectiveness (Huse 1994). Thus, an important factor that may affect the board's ability to monitor the firm's managers is its composition and the percentage of independent directors on the board (Fama \& Jensen 1983; Jensen \& Meckling 1976).

Boards dominated by independent members are arguably in a better position to monitor and control managers (Dunn 1987). As suggested by Patton and Baker (1987), an independent board will encourage management to focus more on the long-term performance of the firm rather than taking short-term actions intended to have a quick payoff in the stock market. In fact, boards dominated by independent outside directors may help to alleviate the agency problem by monitoring and controlling the opportunistic behaviour of management (Jensen \& Meckling 1976). They do this by ensuring that managers are not the sole evaluators of their own performance (Baysinger \& Hoskisson 1990; Pearce \& Zahra 1992); influencing the quality of the deliberations and decisions of directors due to their independence, expertise, prestige and contacts (Grace et al. 1995), and being concerned with maintaining their reputation in the external labour market (Fama \& Jensen 1983). 
Shareholders of firms with independent directors serving on the boards can expect that these directors will maximise managements' behaviours and will distinguish between good and bad decisions made by management (Byrd \& Hickman 1992). Several studies document that external stakeholders demand the presence of independent outside board members to monitor their interests (e.g. Fiegener et al. 2000; Gompers \& Lerner 2001; Gorman \& Sahlman 1989; Huse 1998; Mitchell et al. 1997; Pruthi et al. 2003).

A higher proportion of independent directors on the board leads to a better monitoring activity of the management (Booth et al. 2002). Consequently, independent outside board members may play an important function in monitoring the production of financial statements by the management (Beekes et al. 2004; Frankel et al. 2011; Lynall et al. 2003; Mather \& Ramsay 2006).

Several prior studies document the favorable impact of outside directors on firm decisions aimed at enhancing shareholder wealth (Bai et al. 2004; Cravens \& Wallace 2001; Choi et al. 2007; Cotter et al. 1997) and on constraining opportunistic earnings management activity (Beasley 1996; Dechow et al. 1996; Peasnell et al. 2000, 2005). The evidence indicates consistently that firms with more independent board members have higher quality earnings by reducing earnings management. For example, Dechow et al. (1996) and Beasley (1996), using US data, find that firms with boards dominated by outside directors are less likely to engage in accounting fraud. Xie et al. (2003) report that earnings management is less likely to occur in companies with boards that include independent outside directors. Ajinkya et al. (2005) show that US companies that have a high percentage of outside directors are more likely to make earnings forecasts which are more accurate and give useful information to investors. Peasnell et al. (2000, 2005) find that opportunistic earnings management by UK firms is reduced by increasing the proportion of non-executive directors. Using Canadian data, Park \& Shin (2004) find that the proportion of outside directors on the board reduces the level of earnings management. For a sample of Greek firms, Dimitropoulos \& Asteriou (2010) find that firms with a higher proportion of outside directors (thus greater board independence) report earnings of higher quality (measured by abnormal or discretionary accruals) compared to firms with a low proportion of outside directors. Using French and Canadian data, Jouber \& Fakhfakh (2011) find that less independent boards is associated with greater earnings management. For a sample of Chinese firms, Firth et al. (2007) and Lai \& Tam (2007) find also that independent directors are associated with lower earnings management. Jaggi et al. (2009) document that independent corporate boards of Hong Kong firms provide effective monitoring of earnings management, which suggests that corporate board independence is important to ensure high-quality financial reporting. Using Italian data, Marra et al. (2011) document that the presence of a majority of independent directors decreases earnings management.

In summary, one can confirm that prior research supports the hypothesis that earnings management is reduced in proportion to the number of independent outside directors on the board. This suggests that independent directors improve earnings quality by reducing earnings management.

Firms with higher earnings quality are seen by investors as being more transparent (Hodge 2003). Thus there could be a substitution effect with earnings quality and the level of independent directors on the board (Bushman et al. 2004). If the firm is more transparent, there is probably less need for monitoring and independent director membership. However, where there is lower transparency, governance mechanisms such as independent outside director representation on the board is put in place so as to increase the earnings quality (Dimitropoulos \& Asteriou 2010). Adams et al. (2010) and Bushman (2009) also argue that board independence and managerial discretion are endogenously determined. 
We extend the existing empirical research by evaluating whether the corporate board independence improves earnings quality by reducing earnings management in Portuguese listed firms, addressing additionally the potential simultaneity problem between both. Boards of Portuguese listed firms are commonly organised in a single-tier structure. In this single-tier system, the prescribed role of independent board members is to protect shareholders' interests in key decisions to the firm. CMVM's recommendations also establish that the non-executive members of the board of directors must include a sufficient number of independent members for the supervision, control, and evaluation of executive directors. When there is only one non-executive director, he/she must also be independent.

Based on the conceptual arguments presented in the literature and CMVM's recommendations, we postulate that independent board members improve earnings quality by constraining executives' attempts to earnings management in Portugal.

We test the following hypothesis, stated in the alternative form:

H1: The proportion of independent non-executive directors on the board improves earnings quality by reducing earnings management.

\section{Methodology}

\subsection{Sample Selection and Characteristics}

The initial sample includes all companies whose stocks are listed in the main market, Euronext Lisbon. A total of 50, 48, 51, 51, 51, 50, 49 and 52 companies were listed at the year end of 2003, 2004, 2005, 2006, 2007, 2008, 2009 and 2010 respectively (402 firm-year observations in total).

Foreign companies (30 in total) are excluded, because of the differences in institutional environments. Companies not having shares listed in the previous year and companies whose shares were delisted in the following year are also excluded (66 in total). Companies with missing data (5 in total) and financial companies (37 in total) are also excluded. As a result, the final sample size is 33 non-financial companies per year and, thus, 264 observations in total. This reduced number of observations may influence some results. Nevertheless, this limitation is an immediate consequence of the small size of the Portuguese stock market.

Information on independent board, leverage, operational cash flows, Big4, total assets, revenues, gross property, plant and equipment, receivables and net income are collected from the Annual Report and Corporate Governance Report. Both Annual Report and Corporate Governance Report are available online at www.cmvm.pt. We obtain stock price data from the Euronext Lisbon, which allows measuring the variable firm size and investment opportunities.

Table 1 presents the sample descriptive statistics for the variables used in this research. Table 1 shows that around 30\% (with a median of 28.3\%) of the board members are independent non-executive directors, with a minimum of $0.0 \%$ and a maximum of $59.2 \%$. Leverage variable represents on average 4.406 of the total assets of the company (with a median of 1.985). Cash flows variable represents on average 7.1 of the total assets of the company (with a median of 7.7). The descriptive statistics of the market-to-book ratio show that, on average, firms in our sample exhibit relatively high investment opportunities level with a mean (median) of 1.060 (0.994). Big 4 auditors are used by 69.8 percent of the sample firms. The mean of firm size is about EUR 1.260 million with a minimum of EUR 1.881 thousand and a maximum of EUR 16.345 million. 
Alves | The Effect of Board Independence on the Earnings Quality

Table 1: Summary of Descriptive Statistics

Number of observations: 264; Period: 2003-2010

\begin{tabular}{lccrr}
\hline & Mean & Median & \multicolumn{1}{c}{ Min. } & Max. \\
\hline Independent board & 0.299 & 0.283 & 0.000 & 0.592 \\
Leverage & 4.406 & 1.985 & 0.167 & 20.214 \\
Cash flows & 0.071 & 0.077 & -0.199 & 0.309 \\
Investment opportunities & 1.060 & 0.994 & 0.000 & 3.649 \\
Big4 & 69.787 & 1.000 & 0.000 & 1.000 \\
Firm size & 19.149 & 19.022 & 14.447 & 23.517 \\
\hline
\end{tabular}

Independent board represents the ratio between the number of independent directors and the total number of board members; Leverage represents the ratio between the book value of all liabilities and the total assets; Cash flows is the ratio between the operating cash flows and the total assets; Investment opportunities represents the ratio between the market value of equity and the book value of equity; Big4 dummy variable, which takes a value 1 if the auditor is a Big4; Firm size represents the firm's size.

Table 2: Pearson Correlation Coefficients Matrix

\begin{tabular}{lcclll}
\hline & $\begin{array}{c}\text { Independent } \\
\text { board }\end{array}$ & Leverage & Cash flows & $\begin{array}{c}\text { Investment } \\
\text { opportunities }\end{array}$ & Firm size \\
\hline Independent board & 1 & & & & \\
Leverage & 0.033 & 1 & & & \\
Cash flows & 0.096 & $-0.301^{* *}$ & 1 & 1 & \\
Investment opportunities & -0.008 & -0.135 & $0.271^{* * *}$ & 1 \\
Firm size & $0.179^{* * *}$ & $-0.596^{* *}$ & $0.376^{* * *}$ & 0.003 & 1 \\
\hline
\end{tabular}

Independent board represents the ratio between the number of independent directors and the total number of board members; Leverage represents the ratio between the book value of all liabilities and the total assets; Cash flows is the ratio between the operating cash flows and the total assets; Investment opportunities represents the ratio between the market value of equity and the book value of equity; Firm size represents the firm's size.

*** Correlation is significant at the 0.01 level (2-tailed)

** Correlation is significant at the 0.05 level (2-tailed)

The analysis of Table 2 shows that there are some significant correlations between the variables. The binary variable (Big4) is not included in Table 2, given that the Pearson correlation coefficient is not computed to nominal variables. Firm size and Independent board is positively related, suggesting that the number of independent non-executive directors on the board is positively determined by the size of a firm. A negative correlation between Leverage and Cash flows indicates that firms with high leverage have lower cash flows from operations. Firm size is negatively associated with Leverage, suggesting that larger firms have lower leverage constraint levels. Cash flow is positively correlated with Investment opportunities, suggesting that firms with high levels of cash flow tend to have more investment opportunities. Firm size is positively correlated with Cash flows, suggesting that large firms have greater operating cash flows. Correlation coefficients are in general low, suggesting the absence of serious statistical problems related with multicollinearity (Tabachnick \& Fidell 2001). 


\subsection{Research Design}

\subsubsection{Measuring Independent Board Members}

Independent board is calculated by dividing the number of independent non-executive directors by the total number of board members.

\subsubsection{Measuring Earnings Quality}

Following standard accounting literature, we use discretionary accruals as a proxy for earnings quality. Discretionary accruals are estimated using the cross sectional variation of the modified Jones model proposed by Dechow et al. (1995), which is commonly used by most of earnings quality (or earnings management) researchers (Aboody et al. 2005; Balsam et al. 2003; Hsu \& Koh 2005; Jaggi et al. 2009; Jiang et al. 2008; Johnson et al. 2002; Myers et al. 2003; Qinghua et al. 2007). Furthermore, recently some researchers have argued that current discretionary accruals are the most powerful models for estimating discretionary accruals among the existing models (Ashbaugh et al. 2003; Guay et al. 1996; Jaggi \& Leung 2007).

The modified Jones model consists of regressing total accruals (TACC) on three variables: the change in revenues ( $\Delta \operatorname{Rev})$, the change in receivables $(\triangle \operatorname{Rec})$ and the level of gross property, plant and equipment $(P P E)$. All variables and the intercept are divided by lagged total assets in order to avoid problems of heteroskedasticity. Non-discretionary accruals (NDACC) are the predictions from the ordinary least squares (OLS) estimation of the model (1), while discretionary accruals (DACC) are the residuals.

The modified Jones model is as follows:

$$
\frac{T A C C_{i t}}{T A_{i t-1}}=\alpha_{1}\left(\frac{1}{T A_{i t-1}}\right)+\alpha_{2}\left(\frac{\Delta \operatorname{Re} v_{i t}-\Delta \operatorname{Re} c_{i t}}{T A_{i t-1}}\right)+\alpha_{3}\left(\frac{P P E_{i t}}{T A_{i t-1}}\right)+\varepsilon_{i t}
$$

Where:

$T A C C, T A, \triangle R e v, P P E, I, t=$ as defined previously;

$\Delta R e c=$ change in accounts receivable.

\subsubsection{Control Variables}

Given that the independent directors are not the only factor affecting earnings quality (or earnings management), several control variables are introduced to isolate other contracting incentives that may influence the managers' accounting choices. Previous research suggests that leverage, cash flows, investment opportunities, Big4 and firm size are associated with earnings management (Chen et al. 2011; Chung et al. 2002; Dechow et al. 1995; DeFond \& Jiambalvo 1994; DeFond \& Park 1997; Klein 2002; Peasnell et al. 2005; Xie et al. 2003; Yang et al. 2008).

Leverage is the ratio between the book value of all liabilities and the total assets. Leverage can have a negative or positive influence on earnings quality by reducing managerial opportunism. Previous studies document that managers of highly leveraged firms have strong incentives to use income increasing accruals to loosen the contractual debtconstraints (Ali et al. 2008; DeFond \& Jiambalvo 1994; Jiang et al. 2008). Nevertheless, highly indebted firms may be less able to practice earnings management because they are under close scrutiny by lenders. In this sense, Chung et al. (2002), Park \& Shin (2004), Peasnell et al. (2000) and Yang et al. (2008) find a negative relationship between leverage and earnings management.

Cash Flows is the ratio between the operating cash flows and the total assets. Dechow et al. (1995) show that cash flows influence the magnitude of discretionary accruals, where the ones with higher values are associated with lower discretionary accruals. Chen et al. (2007), 
Jiang et al. (2008), Peasnell et al. (2000) and Yang et al. (2008) also find that firms with strong operating cash flows have lower levels of discretionary accruals.

Investment Opportunities is the ratio between the market value of equity and the book value of equity. Unethical managers may be induced to misstate financial statements when growth slows or reverses, in order to maintain the appearance of consistent growth (Summers \& Sweeney 1998). Trying to meet such expectations could be a major motivation for managers, and discretionary accruals are a useful tool to attain that objective. This suggests that investment opportunities can have a negative influence on earnings quality by increasing earnings management. Iyengar et al. (2010) find a negative association between reported earnings quality and a firm's growth opportunities. In the same sense, AlNajjar \& Belkaoui (2001), Park \& Shin (2004) and Chen et al. (2011) find that firms with higher investment opportunities are more likely to engage in earnings management.

Big4 takes a value 1 if the auditor is a Big4 and 0 otherwise. Managers prefer discretion in the reporting process, and auditors may go along with earnings management behaviour by reporting low quality earnings in order to avoid dismissal by clients (Francis \& Wang 2008). However, a higher quality audit increases the chances of detecting questionable accounting practices, constraining overstated earnings and revealing misreporting (Abdel-Meguid et al. 2011; Francis 2004). Since auditors with a larger client base have to maintain a good reputation to avoid losing contracts, they would perform a higher quality of audit, therefore resulting in a higher quality of reported earnings (Krishnan 2003). Numerous studies suggest that higher quality auditors reduce the level of accrual earnings management (e.g. Becker et al. 1998; Caneghem 2004; Gul et al. 2002; Gul et al. 2006; Jordan et al. 2010; Krishnan 2003; Lin \& Hwang 2010).

Firm Size is calculated as the logarithm of market value of equity. The size hypothesis conjectures that managers of large firms are more likely to exploit latitude in accounting discretion to reduce political attention (Watts \& Zimmerman 1978, 1986, 1990). Banderlipe (2009), Jiang et al. (2008) and Peasnell et al. (2000) find that larger firms are associated with lower absolute discretionary accruals. Nevertheless, larger firms may have higher incentives to manage earnings, as they are subject to closer scrutiny by the investment banks and analyst community, leading them to adopt aggressive accounting policies (Chen et al. 2007). Chen et al. (2007), Chung et al. (2002) and Yang et al. (2008) find that larger firms are associated with higher absolute discretionary accruals.

\subsubsection{Regression models}

To examine the relationship between board independence and earnings management, we first run an ordinary least squares (OLS) regression:

$$
\begin{aligned}
& E Q_{i t}=\beta_{0}+\beta_{1}\left(\text { Independent Board }_{i t}\right)+\beta_{2}\left(\text { Leverage }_{i t}\right)+\beta_{3}\left(\text { Cash flows }_{i t}\right)+\beta_{4} \\
& \left(\text { Investment Opportunities }_{i t}\right)+\beta_{5}\left(\text { Big }_{i t}\right)+\beta_{6}\left(\text { Firm Size }_{i t}\right)+\varepsilon_{\text {it }}
\end{aligned}
$$

Where:

$E Q_{i t}=$ earnings quality of firm $i$ for period $t$ by using the proxy: the modified Jones model;

Independent Board $_{i t}=$ ratio between the number of independent directors and the total number of board members of firm $i$ for period $t$;

Leverage $_{i t}=$ ratio between the book value of all liabilities and the total assets of firm $i$ for period $t$;

Cash flows $_{i t}=$ ratio between the operating cash flows and the total assets of firm $i$ for period $t-1$; 
Investment Opportunities $_{i t}=$ ratio between the market value of equity and the book value of equity;

$B i g 4_{i t}=$ dummy variable: 1 if the auditor is a Big4 and 0 otherwise;

Firm Size $_{i t}=$ logarithm of market value of equity of firm $i$ for period;

$\varepsilon_{i t}=$ residual term of firm $i$ for period $t$;

$\beta_{0}$ is a constant, $\beta_{1}$ to $\beta_{6}$ are the coefficients.

In addition, we run the regression using the two-stage least squares (2SLS) method. 2SLS regression is used as an alternative estimation method when there is a potential simultaneity problem between earnings quality and independent directors. Firms with higher earnings quality are seen by investors as being more transparent (Hodge 2003). Thus there could be a substitution effect with earnings quality and the level of independent directors on the board (Bushman et al. 2004). Board independence is a choice variable which could be affected by some firm-year outcomes and characteristics. Therefore, in the present analysis of Portuguese firms, if the incentive to choose a more independent board is affected by a firm's level of earnings quality, then this posits a potential simultaneity problem in the above regression. If independent board and earnings quality is simultaneously determined, then the OLS estimated coefficients on independent board in (2) will be biased and inconsistent. One way of solving the simultaneity problem is to perform a two-stage least squares (2SLS) analysis.

We use the following two-stage least squares (2SLS) regression specification:

First stage:

Independent Board $_{i t}=\alpha_{0}+\alpha_{1}\left(\right.$ Board Size $\left._{i t}\right)+\alpha_{2}\left(\right.$ Leverage $\left._{i t}\right)+\alpha_{3}($ Cash flows $\left._{i t}\right)+\alpha_{4}$ (Investment Opportunities $\left.i t\right)+\alpha_{5}\left(\right.$ Big4 $\left._{i t}\right)+\alpha_{6}\left(\right.$ Firm Size $\left._{i t}\right)+\eta_{\text {it }}$

Second stage:

$E Q_{i t}=\lambda_{0}+\lambda_{1}\left(\right.$ Independent Board $\left._{i t}\right)+\lambda_{2}$ (Leverage $\left._{i t}\right)+\lambda_{3}\left(\right.$ Cash flows $\left._{i t}\right)+\lambda_{4}$ $\left(\right.$ Investment Opportunities $\left._{i t}\right)+\lambda_{5}\left(\right.$ Big $\left._{i t}\right)+\lambda_{6}\left(\right.$ Firm Size $\left._{i t}\right)+v_{\text {it }}$

Where:

Independent Board is Independent Board after instrumentation with Board Size $e_{i t}$.

Board Size $_{i t}$ is defined as the number of directors on the board of firm $i$ in year $t$.

Board size is used as an instrument for two reasons. Firstly, the fraction of independent directors is likely to be smaller for boards with more members (Chen \& Al-Najjar 2012; Klein 2002; Mak \& Li 2001). Secondly, firms with larger boards presumably can afford to invite outside directors to their boards without sacrificing representation of the insiders (Agrawal \& Knoeber 1996).

To investigate whether an endogeneity problem exists and whether the instruments used are valid, we perform an endogeneity test as well as the Hausman test. For the endogeneity test, the first stage regression is carried out as in (3). The residuals $\hat{\eta}_{\text {it }}$ are obtained and added to the regression in (2) as follows:

$$
\begin{aligned}
& E Q_{i t}=\beta_{0}+\beta_{1}\left(\text { Independent Board }_{i t}\right)+\beta_{2}\left(\text { Leverage }_{i t}\right)+\beta_{3}\left({\text { Cash } \text { flows }_{i t}}\right)+\beta_{4} \\
& \left(\text { Investment Opportunities }_{i t}\right)+\beta_{5}\left(\text { Big }_{i t}\right)+\beta_{6}\left(\text { Firm Size }_{i t}\right)+\beta_{7}\left(\hat{\eta}_{\mathrm{it}}\right)+\varepsilon_{\text {it }}
\end{aligned}
$$

If the coefficient $\beta_{7}$ in (5) is significant, it suggests that an endogeneity problem exists. In the case that an endogeneity problem does not exist, an OLS estimate is more efficient 
than a 2SLS estimate. Nonetheless, the 2SLS estimate is consistent whether a simultaneity problem exists or not, provided that the instruments are valid.

\section{Empirical Results and Discussion}

Table 3 presents both an OLS and 2SLS regressions estimate for equations 2 and 4 developed in section three.

Table 3 - OLS and 2SLS Regressions Results

Number of observations: 264; Period: 2003-2010

\begin{tabular}{|c|c|c|c|c|}
\hline \multirow{3}{*}{$\begin{array}{c}\text { Dependent variable } \\
\text { Independent variables }\end{array}$} & \multicolumn{4}{|c|}{ EQ_ModJones } \\
\hline & \multicolumn{2}{|c|}{ OLS } & \multicolumn{2}{|c|}{ 2SLS } \\
\hline & Coef. & t test & Coef. & t test \\
\hline Constant & 0.549 & $2.579 * * *$ & 0.531 & $2.279 * * *$ \\
\hline Independent board & -0.200 & $-2.205^{* *}$ & -0.161 & $-1.683^{*}$ \\
\hline Leverage & 0.034 & $3.645^{* * *}$ & 0.033 & $3.593 * * *$ \\
\hline Cash flows & -0.300 & $-3.374 * * *$ & -0.297 & $-3.327 * * *$ \\
\hline Investment opportunities & 0.037 & $3.374 * * *$ & 0.036 & $3.274 * * *$ \\
\hline Big4 & 0.211 & 1.276 & 0.212 & 1.277 \\
\hline Firm Size & 0.349 & $8.559 * * *$ & 0.346 & $8.433^{* * *}$ \\
\hline R-squared & \multirow{5}{*}{\multicolumn{2}{|c|}{$\begin{array}{c}33.87 \% \\
32.10 \% \\
19.124 * * *\end{array}$}} & \multicolumn{2}{|c|}{$33.28 \%$} \\
\hline Adjusted R-squared & & & \multicolumn{2}{|c|}{$31.49 \%$} \\
\hline F-statistic & & & \multicolumn{2}{|c|}{$18.623 * * *$} \\
\hline Endogeneity test & & & \multicolumn{2}{|c|}{1.051} \\
\hline Hausman test & & & \multicolumn{2}{|c|}{1.955} \\
\hline
\end{tabular}

EQ_ModJones represents earnings quality estimated from the modified Jones (Dechow et al. 1995) model; Independent board represents the ratio between the number of independent directors and the total number of board members; Leverage represents the ratio between the book value of all liabilities and the total assets; Cash flows is the ratio between the operating cash flows and the total assets; Investment opportunities represents the ratio between the market value of equity and the book value of equity; Big4 dummy variable, which takes a value 1 if the auditor is a Big4; Firm size represents the firm's size.

*** Significant at the 1-percent level; ** Significant at the 5-percent level; * Significant at the 10-percent level.

Table 3 reports the OLS and 2SLS results from equations (2) and (4), respectively, which examine whether independent non-executive members improve earnings quality by reducing earnings management.

The endogeneity test demonstrates that discretionary accruals and board independence are not simultaneously determined. This means that the OLS estimate is not in fact biased and inconsistent. The results of the Hausman's test in Table 3 show that the instrument used is valid in the sense that it is uncorrelated with the error term in the second stage regression, in which Board size is used as the independent board measure. Therefore, the 2SLS estimates in Table 3 are also consistent.

Thus, the results in Table 3 suggest that independent members are significantly negatively related to discretionary accruals, suggesting that managers are less likely to engage in earnings management if the percentage of independent directors is higher. Consequently, firms with a higher percentage of independent directors tend to generate better quality of earnings when compared with the ones with lower percentage. Therefore, these findings seem to indicate that board independence is a key factor influencing the quality of earnings. Our result is consistent with previous studies such as Ajinkya et al. (2005), Beasley 
(1996), Dechow et al. (1996), Jouber \& Fakhfakh (2011), Park \& Shin (2004), Peasnell et al. (2000, 2005) and Xie et al. (2003).

Thus, like in countries characterised by dispersed ownership and well-developed capital markets, the results from a sample of Portuguese firms also indicate that independent nonexecutive members on the board help protect the interests of shareholders and alleviate any conflict of interest between minority outside investors and controlling shareholders/managers.

This result suggests that the board independence may be also effective in code-law countries such as in Anglo-American jurisdictions. In fact, independent directors play a key role in the corporate governance system that has been developed in Europe (e.g. France, Spain and Italy). Consequently, the findings are important to other "Latin, code-law based" countries in Europe. They suggest that a majority of independent directors on their boards of directors enhance the monitoring by the board, particularly the monitoring of the financial reporting process.

Regarding the other variables, included as control variables, we find for both models a positive relationship between the Leverage and discretionary accruals, suggesting that an increase in leverage encourages managers to use more accruals to manage earnings to avoid debt covenant violation. This confirms the prediction and results of DeFond \& Jiambalvo (1994) and Jiang et al. (2008). As a result, leverage seems to have a negative influence on earnings quality. Cash flow is significantly negative in both models, confirming that firms with high levels of cash flows are less likely to use discretionary accruals to engage in earnings management, in agreement with the findings of Chen et al. (2007), Dechow et al. (1995) and Yang et al. (2008). Consequently, these results show that firms with higher cash flow have higher earnings quality.

Consistent with the findings of AlNajjar \& Belkaoui (2001), Park \& Shin (2004) and Chen et al. (2011), we also find for both models that firms with higher investment opportunities are more likely to engage in earnings management. Finally, as in Chen et al. (2007), Chung et al. (2002) and Yang et al. (2008), we find that large firms have a higher level of discretionary accruals. Both investment opportunities and firm size seem to decrease earnings quality.

Results suggest that Big4 do not affect the levels of discretionary accruals.

\section{Sensitivity Analyses}

To ensure the robustness of our results, we perform several sensitivity checks. The first sensitivity analysis is to check whether critical assumptions of statistical analysis - namely, no multicollinearity, homocedasticity and absence of influential observations - are met. There are several formal tests to detect the presence of multicollinearity. There are the zero-order (bivariate) correlation coefficients. Multicollinearity problems occur when variables are highly correlated (say, 0.9 and above). There are also variance inflation factors (VIF) and condition indices (CI). VIF measure the impact of the other independent variables on the standard error of a regression coefficient, while CI measures the dependency of one variable in relation to the others. Large VIF and CI values indicate high degrees of collinearity or multicollinearity among the independent variables. Values of 10.00 and 30.00 are the most commonly used thresholds, respectively. Complementarily, for all condition indices above 30 , multicollinearity exists when a substantial proportion of variance ( 0.90 or above) for two or more coefficients is found (Hair et al. 1998). VIF and CI statistics suggest the absence of multicollinearity problems. Although CI statistics indicate some values slightly greater than the 30 threshold, no dimension has more than two variance proportions greater than 0.90 (values not disclosed). 
Heteroscedasticity does not affect the unbiased and consistent characteristics of estimators. However, they are no longer efficient (i.e., they do not show minimum variance properties) (Hair et al. 1998). $\mathrm{t}$ and $\mathrm{F}$ tests can be highly misleading because confidence intervals are large (Gujarati 1995). A technique commonly used to mitigate the heteroscedasticity problem is to deflate the variables by some proxy for the source of the problem, usually firm size. This is the procedure used in this study. In order to investigate the persistence of heteroscedasticity after financial variables have been deflated by the total assets of the firm, we systematically diagnose the plots of the residuals against the predicted regression. The scatterplots (not reported here) suggest the existence of heterocedasticity in the EQ equations. As a consequence, we transform the EQ variable by computing its natural logarithm. The results (not reported here), when logarithmic transformations of EQ is used to reduce potential heteroscedasticity problems, has implications on investment opportunities variable, which lost significance level (from $\mathrm{p}<0.01$ to $\mathrm{p}<0.10$ ). The other results remain unchanged (at coefficient signal and significant level).

Where outliers are found (namely in the variables Leverage, Cash flow and Investment opportunities), a winserization method is used to test the robustness of the results. Extreme values (defined as values that are more than three standard deviations away from the mean) are replaced by values that are exactly three standard deviations away from the mean. The results (not reported here) do not differ from results presented previously in Table 3. Thus, the influential observations do not affect the results.

The next sensitivity analysis tests the impact of using alternative definition for the earnings quality variable on the regression results. Discretionary accruals are determined using the Jones model instead of the modified Jones model. The Jones model consists of regressing total accruals (TACC) on two variables: the change in revenues ( $\triangle R e v)$, which model the normal component of working capital accruals; and the level of gross property, plant and equipment ( $P P E$ ), included to control the non-discretionary component of depreciation and amortisation expense, the main component of long-term accruals. The specific Jones model is as follows:

$$
\frac{T A C C_{i t}}{T A_{i t-1}}=\alpha_{1}\left(\frac{1}{T A_{i t-1}}\right)+\alpha_{2}\left(\frac{\Delta \operatorname{Re} v_{i t}}{T A_{i t-1}}\right)+\alpha_{3}\left(\frac{P P E_{i t}}{T A_{i t-1}}\right)+\varepsilon_{i t}
$$

Where:

$T A C C=$ total accruals in year $\mathrm{t}$, calculated as the difference between net income and operating cash flows;

$T A=$ total assets at the beginning of year $\mathrm{t}$;

$\triangle R e v=$ change in revenues;

$P P E=$ gross property, plant and equipment;

$\mathrm{i}, \mathrm{t}=$ firm and year index.

The results (not reported here) of the regression, using alternative variable to measure earnings quality, has implications on leverage variable, which lost significance level (from $\mathrm{p}<0.01$ to $\mathrm{p}<0.05$ ). The other results remain unchanged (at coefficient signal and significant level).

We test the impact of using alternative definition for the firm size and the investment opportunities variables on the regression results. Thus, we use logarithm of assets instead of the market value of equity as a proxy for firm size, and the ratio of the market value of the firm to the book value of its assets as a proxy for investment opportunities. The results (not reported here) of the regressions considering alternative variable definition have 
implications on the Cash flow and Investment opportunities variables, which are significant at $5 \%$ level.

Overall, the several sensitivity analyses conducted corroborate the results presented in table 3.

\section{Summary and Conclusions}

Shareholders, due to their inability to directly monitor management behaviours, rely on the board of directors to perform such monitoring activities (Jensen 1993). Inclusion of independent outside directors on the board increases the viability of the board as a mechanism for controlling the actions of management (Fama 1980). In this sense, previous literature suggests that outside independent directors on the board help protect the interests of shareholders and alleviate any conflict of interest between investors and managers (e.g. Dechow \& Dichev 2002; García-Meca \& Sánchez-Ballesta 2009; Koa \& Chen 2004; Mather \& Ramsay 2006; Peasnell et al. 2000, 2005).

Thus, the shareholders' interests are better protected in outside dominated boards, which potentially improve earnings quality. Therefore, this paper examines whether board independence improves earnings quality by reducing earnings management within the Portuguese capital market. Using a sample of 33 non-financial Portuguese firms listed from 2003 to 2010, we conclude that independent board members improve earnings quality by reducing discretionary accruals. In fact, firms with a higher proportion of independent outside directors report earnings of higher quality (measured by discretionary accruals) compared to firms with a low proportion of outside directors. The results suggest that earnings quality of Portuguese listed firms is influenced by the independence of the board.

Moreover, the results also reveal that cash flow has a positive influence on earnings quality, while leverage, investment opportunities and firm size seem to have a negative influence on earnings quality.

The findings of this study make the following contributions. First, the results indicate that, on average, independent members improve earnings quality by providing effective monitoring of earnings management in Portuguese listed firms. This result is interesting given the scrutiny of corporate governance mechanisms and the state of the financial reporting system. Second, the findings are relevant for countries with an institutional environment (mainly concentrated ownership) similar to that of Portugal. Finally, investors may also benefit from the findings because they provide insight into the impact of independent members on earnings quality. In truth, understanding how earnings quality varies with board independence provides potential benefits to investors.

However, this study has some limitations. First, the reduced number of observations may influence some results. Nevertheless, this limitation is an immediate consequence of the small size of the Portuguese stock market. Second, we compute discretionary accruals using the modified Jones model (Dechow et al. 1995). Although the model is accepted in accounting research, the accuracy of measurement of discretionary accruals will depend on how accurately the model can segregate discretionary accruals from total accruals. Finally, the selection of the control variables can lead to the omission of some important determinants of earnings quality. This mis-specification can generate biased and inconsistent estimates. Actually, other factors can influence the earnings quality, such as managerial ownership (Ali et al. 2008; Beekes et al. 2004), board size (Ebrahim 2007; Eisenberg et al. 1998; Xie et al. 2003), CEO duality (Davidson et al. 2004), audit committee (Balsam et al. 2003; Becker et al. 1998; Francis et al. 1999) and the managerial compensation structure (Guidry et al. 1999; Healy 1985; Holthausen et al. 1995). 
Alves | The Effect of Board Independence on the Earnings Quality

\section{References}

Abdel-Meguid, A, Ahmed, A \& Duellman, S 2011, 'Auditor independence, corporate governance and aggressive financial reporting: an empirical analysis', Journal of Management and Governance, vol. 12, pp. 1-25.

Aboody, D, Hughes, J \& Liu, J 2005, 'Earnings Quality, Insider Trading, and Cost of Capital', Journal of Accounting Research vol. 43, no. 5, pp. 651-673. http://dx.doi.org/10.1111/j.1475-679X.2005.00185.x

Adams, RB, Hermalin, BE, \& Weisback, MS 2010, 'The role of boards of directors in corporate governance: A conceptual framework and survey', Journal of Economic Literature, vol. 48, no. 1, pp. 58-107. http://dx.doi.org/10.1257/jel.48.1.58

Ahmed, AS \& Duellman, S 2007, 'Accounting conservatism and board of director characteristics: An empirical analysis', Journal of Accounting and Economic, vol. 43, no. 2-3, pp. 411-437. http://dx.doi.org/10.1016/j.jacceco.2007.01.005

Agrawal, A \& Knoeber, CR 1996, 'Firm Performance and Mechanisms to Control Agency Problems Between Managers and Shareholders', Journal of Financial and Quantitative Analysis, vol. 31, no. 3, pp. 377-397. http://dx.doi.org/10.2307/2331397

Ajinkja, B, Bhojraj, S \& Sengupta, P 2005, 'The Association between Outside Directors, Institutional Investors and the Properties of Management Earnings Forecasts', Journal of Accounting Research, vol. 43, no. 3, pp. 343-376. http://dx.doi.org/10.1111/j.1475679x.2005.00174.x

Ali, SM, Salleh, NM \& Hassan, MS 2008, 'Ownership Structure and Earnings Management in Malaysian Listed Companies: the size effect', Asian Journal of Business and Accounting, vol. 1, no. 2, pp. 89-116.

AlNajjar, F \& Belkaoui, AR 2001, 'Growth opportunities and earnings management', Managerial Finance, vol. 27, no. 12, pp. 72-81. http://dx.doi.org/10.1108/03074350110767457

Alves, C \& Mendes, V 2001, 'Corporate governance policy and company performance: The case of Portugal', Working Paper, University of Porto.

Ashbaugh, H, LaFond, R \& Mayhew, B 2003, 'Do non audit services compromise auditor independence? Further evidence', The Accounting Review, vol. 78, no. 3, pp. 611-639. http://dx.doi.org/10.2308/accr.2003.78.3.611

Bai, C, Liu, Q, Lu, J, Song, FM \& Zhang, J 2004, 'Corporate governance and market valuation in China', Journal of Comparative Economics, vol. 32, no. 4, pp. 599-616. http://dx.doi.org/10.1016/j.jce.2004.07.002

Balsam, S, Krishnan, J \& Yang, JS 2003, 'Auditor industry specialization and earnings quality', Auditing: A Journal of Practice and Theory, vol. 22, no. 2, pp. 71-97.

Banderlipe, MRS 2009, 'The impact of selected corporate governance variables in mitigating earnings management in the Philippines', DLSU Business \& Economics Review, vol. 19, no. 1, pp. 17-27. http://dx.doi.org/10.3860/ber.v19i1.1110

Baysinger, BD \& Hoskisson, RR 1990, 'The composition of boards of directors and strategic control: effects on corporate strategy', Academy Management Review, vol. 15, no. 1, pp. 72-87.

Beasley, MS 1996, 'An Empirical Analysis of the Relation Between the Board of Director Composition and Financial Statement Fraud', The Accounting Review, vol. 71, no. 4, pp. 443-465.

Becker, CL, DeFond, ML, Jiambalso, J \& Subramanyam, KR 1998, 'The Effect of Audit Quality on Earnings Management', Contemporary Accounting Research, vol. 15, no. 1, pp. 1-24. http://dx.doi.org/10.1111/j.1911-3846.1998.tb00547.x 
Beekes, W, Pope, P \& Young, S 2004, 'The Link Between Earnings Timeliness, Earnings Conservatism and Board Composition: evidence from the UK', Corporate Governance, vol. 12, no. 1, pp. 47-59. http://dx.doi.org/10.1111/j.1467-8683.2004.00342.x

Booth, JR, Cornett, MM \& Tehranian, H 2002, 'Board of directors, ownership, and regulation', Journal of Banking and Finance, vol. 26, no. 10, pp. 1973-1996. http://dx.doi.org/10.1016/S0378-4266(01)00181-9

Bushman, RM, Chen, Q, Engel, E \& Smith, A 2004, 'Financial accounting information, organizational complexity and corporate governance systems', Journal of Accounting and Economics, vol. 37, no. 2, pp. 167-201. http://dx.doi.org/10.1016/j.jacceco.2003.09.005

Bushman, RM 2009, “Weak” governance may be optimal governance: A discussion of "Corporate governance and backdating of executive stock options"', Contemporary Accounting Research, vol. 26, no. 2 (Summer), pp. 447-451. http://dx.doi.org/10.1506/car.26.2.5

Byrd, J \& Hickman, K 1992, 'Do Outside Directors Monitor Managers?', Journal of Financial Economics, vol. 32, no. 2, pp. 195-221. http://dx.doi.org/10.1016/0304$\underline{405 X(92) 90018-S}$

Caneghem, TV 2004, 'The Impact of Audit Quality on Earnings Rounding-up Behaviour: Some UK Evidence', European Accounting Review, vol. 13, no. 4, pp. 771-786. http://dx.doi.org/10.1080/0963818042000216866

Chen, CH \& Al-Najjar, B 2012, 'The determinants of board size and independence: Evidence from China’, International Business Review, vol. 21, no. 5, pp. 831-846. http://dx.doi.org/10.1016/j.ibusrev.2011.09.008

Chen, KY, Elder, RJ \& Hsieh, YM 2007, 'Corporate governance and earnings management: The implications of corporate governance best-practice principles for Taiwanese listed companies', Journal of Contemporary Accounting \& Economics, vol. 3, no. 2, pp. 73105. http://dx.doi.org/10.1016/S1815-5669(10)70024-2

Chen, X, Cheng, Q \& Wang, X 2011, 'Does increased board independence reduce earnings management? Evidence from recent regulatory reforms', Working Paper.

Choi, JJ, Park, SW, Yoo, SS 2007, 'The value of outside directors: Evidence from corporate governance reform in Korea', Journal of Financial and Quantitative Analysis, vol. 42, no. 4, pp. 941-962. http://dx.doi.org/10.1017/S0022109000003458

Chung, R, Firth M \& Kim, JB 2002, 'Institutional monitoring and opportunistic earnings management', Journal of Corporate Finance, vol. 8, no. 1, pp. 29-48. http://dx.doi.org/10.1016/S0929-1199(01)00039-6

CMVM Regulation 10/1999, 'Recommendations on corporate governance', available at: www.cmvm.pt.

CMVM Regulation 7/2001, 'Recommendations on corporate governance', available at: www.cmvm.pt.

CMVM Regulation 11/2003, 'Recommendations on corporate governance', available at: www.cmvm.pt.

CMVM Regulation 10/2005, 'Recommendations on corporate governance', available at: www.cmvm.pt.

CMVM Regulation 3/2006, 'Recommendations on corporate governance', available at: www.cmvm.pt.

Cotter, JF, Shivdasani, A \& Zenner, M 1997, 'Do Independent Directors Enhance Target Shareholder Wealth During Tender Offers?', Journal of Financial Economics, vol. 43, no. 2, pp. 195-218. http://dx.doi.org/10.1016/S0304-405X(96)00886-0 
Cravens, K \& Wallace, W 2001, 'A framework for determining the influence of corporate board of directors in accounting studies', Corporate Governance, vol. 9, no. 1, pp. 2-24. http://dx.doi.org/10.1111/1467-8683.00222

Davidson, R, Goodwin-Stewart, J \& Kent, P 2005, 'Internal governance structures and earnings management', Accounting and Finance, vol. 45, no. 2, pp. 241-267. http://dx.doi.org/10.1111/j.1467-629x.2004.00132.x

Davidson, WN, Jiraporn, P, Kim, YS \& Nemec, C 2004, 'Earnings management following duality-creating successions: Ethnostatistics impression management, and agency theory', Academy of Management Journal, vol. 47, no. 2, pp. 267-275. http://dx.doi.org/10.2307/20159577

Dechow, PM \& Dichev, I 2002, 'The quality of accruals and earnings: The role of accrual estimation errors', The Accounting Review, vol. 77 (Supplement), pp. 35-59. http://dx.doi.org/10.2308/accr.2002.77.s-1.35

Dechow, PM, Sloan, RG \& Sweeney, AP 1995, 'Detecting Earnings Management', The Accounting Review, vol. 70, no. 2, pp. 193-225.

Dechow, PM, Sloan, RG \& Sweeney, AP 1996, 'Causes and consequences of earnings manipulations: An analysis of firms subject to enforcement actions by the SEC', Contemporary Accounting Research, vol. 13, no. 1, pp. 1-36. http://dx.doi.org/10.1111/j.1911-3846.1996.tb00489.x

DeFond, ML \& Jiambalvo, J 1994, 'Debt Covenant Violation and Manipulations of Accruals', Journal of Accounting and Economics, vol. 17, no. 1-2, pp. 145-176. http://dx.doi.org/10.1016/0165-4101(94)90008-6

DeFond, ML \& Park, CW 1997, 'Smoothing income in anticipation of future earnings', Journal of Accounting and Economics, vol. 23, no. 1, pp. 115-139. http://dx.doi.org/10.1016/S0165-4101(97)00004-9

Dimitropoulos, P.E. and Asteriou, D. 2010, 'The effect of board composition on the informativeness and quality of annual earnings: Empirical evidence from Greece', Research in International Business and Finance, vol. 24, no. 2, pp. 190-205. http://dx.doi.org/10.1016/j.ribaf.2009.12.001

Dunn, DJ 1987, 'Directors aren’t doing their jobs', Fortune (March), pp. 117-119.

Ebrahim, A 2007, 'Earnings management and board activity: An additional evidence', Review of Accounting and Finance, vol. 6, no. 1, pp. 42-58. http://dx.doi.org/10.1108/14757700710725458

Eisenberg T, Sundgren, S Wells, MT 1998, 'Larger Board Size and Decreasing Firm Value in Small Firms’, Journal of Financial Economics, vol. 48, no. 1, pp. 35-54. http://dx.doi.org/10.1016/S0304-405X(98)00003-8

Eisenhardt, KM 1989, 'Agency theory: an assessment and review', Academy of Management Review, vol. 14, no. 1, pp. 57-75.

Epps, RW \& Ismail, TH 2009, 'Board of directors' governance challenges and earnings management', Journal of Accounting \& Organizational Change, vol. 5, no. 3, pp. 390416. http://dx.doi.org/10.1108/18325910910986981

Fama, EF 1980, 'Agency Problems and the Theory of the Firm', Journal of Political Economy, vol. 88, no. 2, pp. 288-307. http://dx.doi.org/10.1086/260866

Fama, EF \& Jensen, MC 1983, 'Separation of Ownership and Control, The Journal of Law and Economics’, vol. 2, no. 26, pp. 301-325. http://dx.doi.org/10.1086/467037

Farber, DB 2005, 'Restoring trust after fraud: Does corporate governance matter?', The Accounting Review, vol. 80, no. 2, pp. 539-561. http://dx.doi.org/10.2308/accr.2005.80.2.539 
Fiegener, MK, Brown, BM, Dreux, DR \& William, JD 2000, 'CEO Stakes and Board Composition in Small Private Firms', Entrepreneurship: Theory and Practice, vol. 24, no. 4, pp. 5-24.

Fields, MA \& Keys, PY 2003, 'The Emergence of Corporate Governance from Wall St. to Main St.: Outside Directors, Board Diversity, Earnings Management, and Managerial Incentives to Bear Risk', The Financial Review, vol. 38, no. 1, pp. 1-24. http://dx.doi.org/10.1111/1540-6288.00032

Firth, M, Fung, PMY \& Rui, OM 2007, 'Ownership, two-tier board structure, and the informativeness of earnings - Evidence from China', Journal of Accounting and Public Policy, vol. 26, no. 4, pp. 463-496. http://dx.doi.org/10.1016/j.jaccpubpol.2007.05.004

Francis, JR, Maydew, EL \& Sparks, HC 1999, 'The role of Big 6 auditors in the credible reporting of accruals', Auditing: A Journal of Practice and Theory, vol. 18, no. 2, pp. 17-34.

Francis, JR 2004, 'What Do We Know About Audit Quality?', The British Accounting Review, vol. 36, no. 4, pp. 345-368. http://dx.doi.org/10.1016/j.bar.2004.09.003

Francis, JR \& Wang, D 2008, 'The Joint Effect of Investor Protection and Big 4 Auditors on Earnings Quality Around the World', Contemporary Accounting Research, vol. 25, no. 1, pp. 157-191. http://dx.doi.org/10.1506/car.25.1.6

Frankel, R, McVay, S \& Soliman, M 2011, 'Non-GAAP earnings and board independence', Review of Accounting Studies, vol. 16, no. 4, pp. 719-744. http://dx.doi.org/10.1007/s11142-011-9166-3

García-Meca, E \& Sánchez-Ballesta, J 2009, 'Corporate Governance and Earnings Management: A Meta-Analysis', Corporate Governance: An International Review, vol. 17, no. 5, pp. 594-610.

Garcia Osma, B 2008, 'Board Independence and Real Earnings Management: The Case of R\&D Expenditure’, Corporate Governance, vol. 16, no. 2, pp. 116-131. http://dx.doi.org/10.1111/j.1467-8683.2008.00672.x

Gompers, P \& Lerner, J 2001, 'The Venture Capital Revolution', Journal of Economic Perspectives, vol. 15, no. 2, pp. 145-168. http://dx.doi.org/10.1257/jep.15.2.145

Gorman, M \& Sahlman, WA 1989, 'What Do Venture Capitalists Do?', Journal of Business Venturing, vol. 4, no. 4, pp. 231-249. http://dx.doi.org/10.1016/0883-9026(89)90014-1

Grace. M, Ireland, A \& Dunstan, K 1995, 'Board composition, non-executive directors' characteristics and corporate financial performance', Asia-Pacific Journal of Accounting, vol. 2, no. 1, pp. 121-137. http://dx.doi.org/10.1080/10293574.1995.10510481

Guay, W, Kothari, S \& Watts, R 1996, 'A market-based evaluation of discretionary accrual models', Journal of Accounting Research, vol. 34 (Supplement), pp. 83-105. http://dx.doi.org/10.2307/2491427

Guidry, F, Leone, AJ \& Rock, S 1999, 'Earnings-based bonus plans and earnings management by business-unit managers', Journal of Accounting and Economics, vol. 26, no. 1-3, pp. 113-142. http://dx.doi.org/10.1016/S0165-4101(98)00037-8

Gujarati, DN 1995, Basic Econometrics, 3rd edn, McGraw-Hill Inc., New York.

Gul, F, Lynn, S \& Tsui, J 2002, 'Audit Quality, Management Ownership, and the Informativeness of Accounting Earnings', Journal of Accounting, Auditing and Finance, vol. 17, no. 1, pp. 25-51.

Gul, FA, Tsui, J \& Dhaliwal, DS 2006, 'Non-audit Services, Auditor Quality and the Value Relevance of Earnings', Accounting and Finance, vol. 46, no. 5, pp. 797-817.

Hair, JF, Anderson, RE, Tatham, RL \& Black, WC 1998, Multivariate data analysis, 5th edn, Prentice-Hall Inc., New Jersey. 
Healy, PM 1985, 'The effect of bonus schemes on accounting decisions', Journal of Accounting and Economics, vol. 7, no. 1-3, pp. 85-107. http://dx.doi.org/10.1016/01654101(85)90029-1

Higgs, D 2003, Review of the effectiveness of non-executive directors, Department of Trade and Industry, London.

Hodge, F 2003, 'Investors' perceptions of earnings quality, auditor independence, and the usefulness of audited financial information', Accounting Horizons, vol. 17 (Supplement), pp. 37-48. http://dx.doi.org/10.2308/acch.2003.17.s-1.37

Holderness, CG 2003, 'A survey of blockholders and corporate control', Economic Policy Review, vol. 9, no. 1, pp. 51-64.

Holthausen, RW, Larcker, D \& Sloan, RG 1995, 'Annual bonus schemes and the manipulation of earnings', Journal of Accounting and Economics, vol. 19, no. 2-3, pp. 29-74. http://dx.doi.org/10.1016/0165-4101(94)00376-G

Hsu, GCM \& Koh, PS 2005, 'Does the Presence of Institutional Investors Influence Accruals Management? Evidence from Australia', Corporate Governance, vol. 13, no. 6, pp. 809823. http://dx.doi.org/10.1111/j.1467-8683.2005.00472.x

Huse, M 1994, 'Board-Management Relations in Small Firms: The Paradox of Simultaneous Independence and Interdependence', Small Business Economics, vol. 6, no. 1, pp. 55-72. http://dx.doi.org/10.1007/BF01066112

Huse, M 1998, 'Researching the Dynamics of Board-Stakeholder Relations', Long Range Planning, vol. 22, no. 1, pp. 218-226. http://dx.doi.org/10.1016/S0024-6301(98)00006-5

Iyengar, RJ, Land, J \& Zampelli, EM 2010, 'Does board governance improve the quality of accounting earnings?’, Accounting Research Journal, vol. 23, no. 1, pp. 49-68. http://dx.doi.org/10.1108/10309611011060524

Jaggi, B \& Leung, S 2007, 'Impact of family dominance on monitoring of earnings management by audit committees: Evidence from Hong Kong', Journal of International Accounting Auditing \& Taxation, vol. 16, no. 1, pp. 27-50. http://dx.doi.org/10.1016/j.intaccaudtax.2007.01.003

Jaggi, B, Leung, S \& Gul, F 2009, 'Family control, board independence and earnings management: Evidence based on Hong Kong firms', Journal of Accounting and Public Policy, vol. 28, no. 4, pp. 281-300. http://dx.doi.org/10.1016/j.jaccpubpol.2009.06.002

Jensen, MC \& Meckling, WH 1976, 'Theory of the Firm: Managerial Behavior, Agency and Ownership Structure', Journal of Financial Economics, vol. 3, no. 4, pp. 305-360. http://dx.doi.org/10.1016/0304-405X(76)90026-X

Jensen, MC 1993, 'The Modern Industrial Revolution, Exit, and the Failure of Internal Control Systems', The Journal of Finance, vol. 3, no. 48, pp. 831-880. http://dx.doi.org/10.1111/j.1540-6261.1993.tb04022.x

Jiang, W, Lee, P \& Anandarajan, A 2008, 'The association between corporate governance and earnings quality: Further evidence using the GOV-score', Advances in Accounting incorporating Advances in International Accounting, vol. 24, no. 2, pp. 191-201.

Johnson, VE, Khurana, IK \& Reynolds, JK 2002, 'Audit-firm tenure and the quality of financial reports', Contemporary Accounting Research, vol. 19, no. 4, pp. 637-660. http://dx.doi.org/10.1506/LLTH-JXQV-8CEW-8MXD

Jordan, CE, Clark, SJ \& Hames, CC 2010, 'The Impact of Audit Quality on Earnings Management to Achieve User Reference Points In EPS', Journal of Applied Business Research, vol. 26, no. 1, pp. 19-30.

Jouber, H \& Fakhfakh, H 2011, 'Earnings management and board oversight: an international comparison', Managerial Auditing Journal, vol. 27, no. 1, pp. 66-86. http://dx.doi.org/10.1108/02686901211186108 
Kao, L \& Chen, A 2004, 'The effects of board characteristics on earnings management', Corporate Ownership and Control, vol. 1, no. 3, pp. 96-107.

Klein, A 2002, 'Audit Committee, Board of Director Characteristics, and Earnings Management', Journal of Accounting and Economics, vol. 33, no. 3, pp. 375-400. http://dx.doi.org/10.1016/S0165-4101(02)00059-9

Krishnan, GV 2003, 'Does big 6 auditor industry expertise constrain earnings management?', Accounting Horizons, vol. 17 (Supplement), pp. 1-16. http://dx.doi.org/10.2308/acch.2003.17.s-1.1

La Porta, R, Lopez-de-Silanes, F, Shleifer, A \& Vishny, R 2000, 'Investor Protection and Corporate Governance’, Journal of Financial Economics, vol. 58, no. 1-2, pp. 3-27. http://dx.doi.org/10.1016/S0304-405X(00)00065-9

Lai, L \& Tam, H 2007, 'Independent Directors and the Propensity to Smooth Earnings: A study of Corporate Governance in China', The Business Review, vol. 7, no. 1, pp. 328335.

Lin, JW \& Hwang, MI 2010, 'Audit Quality, Corporate Governance, and Earnings Management: A Meta-Analysis', International Journal Auditing, vol. 14, no. 1, pp. 5777. http://dx.doi.org/10.1111/j.1099-1123.2009.00403.x

Lynall, MD, Golden, BR \& Hillman, A 2003, 'Board Composition From Adolescence to Maturity: A Multitheoretic View’, Academy of Management Review vol. 28, no. 3, pp. 416-432.

Mak, Y \& Li, Y 2001, 'Determinants of corporate ownership and board structure: evidence from Singapore', Journal of Corporate Finance, vol. 7, no. 3, pp. 235-256. http://dx.doi.org/10.1016/S0929-1199(01)00021-9

Marra, A, Mazzola, P \& Prencipe, A 2011, 'Board Monitoring and Earnings Management Pre- and Post-IFRS', The International Journal of Accounting, vol. 46, no. 2, pp. 205230. http://dx.doi.org/10.1016/j.intacc.2011.04.007

Mather, P \& Ramsay, A 2006, 'The Effects of Board Characteristics on Earnings Management around Australian CEO Changes', Accounting Research Journal, vol. 19, no. 2, pp. 78-93. http://dx.doi.org/10.1108/10309610680000680

Mitchell, F, Reid, G \& Terry, N 1997, 'Venture Capital Supply and Accounting Information System Development', Entrepreneurship: Theory and Practice, vol. 21, no. 4, pp. 4562.

Myers, J, Myers, L \& Omer, T 2003, 'Exploring the term of the auditor-client relationship and the quality of earnings: a case for mandatory auditor rotation?', The Accounting Review, vol. 78, no. 3, pp. 779-799. http://dx.doi.org/10.2308/accr.2003.78.3.779

Park, YW \& Shin, HH 2004, 'Board composition and earnings management in Canada', Journal of Corporate Finance, vol. 10, no. 3, pp. 431-457. http://dx.doi.org/10.1016/S0929-1199(03)00025-7

Patton, A \& Baker, JC 1987, 'Why don’t directors rock the boat?', Harvard Business Review, vol. 65, no. 6, pp. 10-18.

Pearce, J \& Zahra, S 1992, 'Board composition from a strategic contingency perspective', Journal of Management Studies, vol. 29, no. 4, pp. 411-438. http://dx.doi.org/10.1111/j.1467-6486.1992.tb00672.x

Peasnell, KV, Pope, PF \& Young, S 2000, 'Accrual Management to meet earnings targets: UK evidence pre- and post-Cadbury’, British Accounting Review, vol. 32, no. 4, pp. 415-445. http://dx.doi.org/10.1006/bare.2000.0134

Peasnell, KV, Pope, PF \& Young, S 2005, 'Board monitoring and earnings management: do outside directors influence abnormal accruals?', Journal of Business Finance and 
Accounting, vol. 32,no. 7-8, pp. 1311-1346. http://dx.doi.org/10.1111/j.0306$\underline{686 X .2005 .00630 . x}$

Pruthi, S, Wright, M. \& Lockett, A 2003, 'Do Foreign and Domestic Venture Capital Firms Differ in their Monitoring of Investees?', Asia Pacific Journal of Management, vol. 20, no. 2, pp. 175-204. http://dx.doi.org/10.1023/A:1023840432241

Qinghua, W, Pingxin, W \& Junming, Y 2007, 'Audit committee, board characteristics and quality of financial reporting: An empirical research on Chinese securities market', Frontiers of Business Research in China, vol. 1, no. 3, pp. 385-400. http://dx.doi.org/10.1007/s11782-007-0023-y

Sarbanes-Oxley Act 2002, Public Law 107-204, 116 Statutes of Large 745.

Shleifer, A \& Vishny, RW 1997, 'A survey of corporate governance’, Journal of Finance, vol. 52, no. 2, pp. 737-783. http://dx.doi.org/10.1111/j.1540-6261.1997.tb04820.x

Silva, AS, Vitorino, A, Alves, CF, Cunha, JA \& Monteiro, MA, 2006, Livro Branco sobre Corporate Governance em Portugal (White Book on Corporate Governance in Portugal), Instituto Português de Corporate Governance.

Summers, SL \& Sweeney, JT, 1998, 'Fraudulently misstated financial statements and insider trading: An empirical analysis', The Accounting Review, vol. 73, no. 1, pp. 131-145.

Tabachnick, BG \& Fidell, LS 2001, Using Multivariate Statistics, Allyn and Bacon, New York.

Uzun, H, Szewczyk, SH \& Varma, R 2004, 'Board composition and corporate fraud', Financial Analysts Journal, vol. 60, no. 3, pp. 33-43. http://dx.doi.org/10.2469/faj.v60.n3.2619

Watts, RL \& Zimmerman, JL 1978, 'Towards a positive theory of the determination of accounting standards', The Accounting Review, vol. 53, no. 1, pp. 112-134.

Watts, RL \& Zimmerman, JL 1986, Positive Accounting Theory, Prentice Hall, Englewood Cliffs, NJ.

Watts, RL \& Zimmerman, JL 1990, 'Positive accounting theory: a ten year perspective', The Accounting Review, vol. 65, no. 1, pp. 131-156.

Xie, B, Davidson, WN \& DaDalt, PJ 2003, 'Earnings management and corporate governance: the role of the board and the audit committee', Journal of Corporate Finance, vol. 9, no. 3, pp. 295-316. http://dx.doi.org/10.1016/S0929-1199(02)00006-8

Yang, CY, Lai, HN and Tan, BL 2008, 'Managerial Ownership Structure and Earnings Management', Journal of Financial Reporting \& Accounting, vol. 6, no. 1, pp. 35-53. http://dx.doi.org/10.1108/19852510880000634 
AABFJ | Volume 8, no. 3, 2014 